\title{
OPEN INNOVATION AND BUSINESS PERFORMANCE IMPROVEMENT IN STRATEGIC BUSINESS ALLIANCES*
}

\author{
Aleksander Strašek ${ }^{* *}$ \\ Franci Pušavec ${ }^{* * *}$ \\ Borut Likar ${ }^{* * * *}$
}

Received: 17. 2. 2020

Preliminary communication

Accepted: 31. 5. 2020

UDC 005.21

DOI https://doi.org/10.30924/mjcmi.25.1.8

\begin{abstract}
The purpose of the research was to investigate whether the comp5anies involved in strategic business alliances (henceforth referred to as the SBA) have a higher level of open innovation and better business results in the metal industry in the EU country, namely Slovenia. The survey was carried out in 115 companies, where the aforementioned relations and their influence were studied applying appropriate statistical methods (e.g. the Mann-Whitney Test, Chi-Square statistics, $t$-test, etc.). The sample encompassed four clusters and $R \& D$ centres from metalprocessing industry. The results showed that SBA have a significantly strong impact on companies' open innovation as well as more efficient cooperation with universities and research institutions. Among the companies involved in SBA, the portion of innovations generated in cooperation with their business partners accounted for $57.7 \%$, while those, not involved in SBA, the same indicator amounts to $19 \%$. In addition, the results showed that the majority of business results, in companies involved in SBA, were above average, compared to the industry sector average values. The value added per employee within companies
\end{abstract}

involved in the SBA was significantly higher than the industry average, as well as the profits; difference was more than threefold. It may be concluded that SBA represent an important bridge in the transformation from a closed innovation model to a model of open innovation, resulting in better business performance. Important implication for companies is related to the message that cooperation with competitors may bring value added to all companies involved.

Keywords: innovation, strategic alliance, open innovation, business performance

\section{INTRODUCTION}

Notwithstanding the strategic importance of innovation, the European Union (EU) is still losing ground in business exploitation of knowledge and creativity to the United States and Japan (UNU-MERIT, 2012). Consequently, the European Union's Lisbon objective of becoming the world's most competitive business environment by

\footnotetext{
* The research was firstly presented at the MARGI conference in Beijing (Strašek \& Likar, 2016). We would like to express our gratitude to organizers and participants. The fruitful discussions helped us to prepare a final paper. ** Aleksander Strašek, M. Sc., EMO Orodjarna d. o. o., Slovenia, E-mail: sandi.strasek@emo-orodjarna.si

${ }^{* * *}$ Franci Pušavec, PhD, Associate professor, University of Ljubljana, Faculty of Mechanical Engineering, Slovenia, E-mail: Franci.Pusavec@fs.uni-lj.si

${ }^{* * * * *}$ Borut Likar (Corresponding author), PhD, Professor, University of Primorska, Faculty of Management, Koper, Slovenia, E-mail: borut.likar1@guest.arnes.si
} 


\section{Journal of Contemporary Management Issues}

2010 was not met. In Slovenia, the overall innovation performance is even slightly below the EU-27 average (UNU-MERIT, 2012). In addition, China, India and Brazil are becoming more and more important players in R\&D. To improve the current situation, further research with a focus on the study of systemic and systematic approaches is required (Drejer, 2008). One of such approaches is connected with an improvement of cross-functional nature of work and is often multi-actor (Hobday, 2005). In particular, companies have recognised that it is crucial to strive towards improving innovation cooperation (Hobday, 2005; Likar, 2008; Ostojić, 2015). This shall not be limited to cooperation within a company only, yet also with the external environment. Engaging in open innovation facilitates a company to overcome its limitations in innovating, i.e. limited resources, supposing the innovation partners have a complementary and active role in innovation activities (Lindegaard, 2011).

As already stated by Betz (1993, 15), it is necessary to deal with different strategies and different organizational characteristics, in order to maintain a competitive advantage and be successful. Dolinšek (2004, 9) states that the most important thing for each company in the next century will be the understanding of the role of innovation and the importance of knowledge, in order to manage technologies and ensure a successful transfer of knowledge and technologies within the company itself or with the integration of the external environment. The author states that it will also be crucial how knowledge from research organizations, universities and state institutions is obtained. Similarly, Kopač (2003, 574) thinks that with the exchange of useful and necessary information and with the simultaneous implementation of the project activities, the planning time and the production of the final product are greatly shortened. It should be noted that, without adequate specific knowledge of all participants in the project, aforementioned shortening of the project time is not even feasible.

Nowadays, companies in fact can no longer rely solely on its internal resources, but must cooperate with partners to obtain missing complementary resources (Cauley de la Sierra, 1994, 5). Strategic alliances and strategic partnerships are modern forms of creating, maintaining and increasing competitiveness in the global market environment. The growing competition in all respects requires more cooperation among companies on the one hand, as well as among their suppliers, customers, competitors and providers of individual functions on the other. With the globalization of the international commerce, when the boundaries between countries or regional areas are fading, a classical definition of the origin of the product and dimensions of a competitive process are changing (Dubrovski, 2009, 51). In addition, we should also mention that it is necessary to maintain the strategic ties with the knowledge centres as well, such as universities and institutes, and regional or global research and development agencies. The objectives of the strategic business relations on the one hand relate to solving development problems and on the other hand to exploiting opportunities. It means that they aim either at elimination of the deficit in available funds and/or at optimal and complementary synergy exploitation of the available resources of the participants' federations and individual companies which do not control all key performance areas, or they are not worth it (Dubrovski ,2009, 243). Konda $(2010,93)$ states that on the basis of strategic planning a company enters into strategic business alliances. The company's success partly depends on its 
needs, experiences with cooperation and the ability to develop cooperation with partners or the focus on the future. The success of cooperation is measured by the total performance, profit, sales, company growth, market share, market share growth and potential of the capital. According to several authors and researchers, it is not always rational for companies, research institutions and universities to implement the whole development by themselves. There should be a new model for a more efficient and faster development and a rapid penetration in the existing as well as in the new markets. By creating a common development area companies gain new opportunities that will eventually become a necessity.

In reviewing the available literature, we have not found a clear and simple model for the determination of benefits that companies have from the strategic business alliances in connection to innovation. Therefore, we decided to develop a concept and on the basis of the latter the research in companies was conducted. The main purpose of the research is to determine the link between strategic business alliances and open innovation (henceforth referred to as the $\mathrm{OI}$ ) on one hand and the business performance on the other. Based on these findings, we would like to provide guidance for the successful transition from a closed innovation model to an open innovation model. Further purpose is to approve or reject the assumptions and hypotheses that the OI is associated with strategic alliances, universities or R\&D institutions. At the same time, we intend to examine the impact of the integration on the business results and the performance of the companies. Furthermore, we were interested in whether the companies involved in strategic alliances manage the innovation more comprehensively.

\section{RESEARCH METHODOLOGY}

The basic thesis of the research is that the strategic business alliances represent the bridge in the transformation from a closed innovation model to an open innovation model. Based on the established purpose, we set two hypotheses:

- H1: Companies with strategic business cooperation have a higher level of open innovation.

- H2: The business results of the companies involved in the strategic business alliances are above average in comparison to the overall sector.

The research was conducted on the basis of a questionnaire (close-ended questions). The questionnaire consisted of sets for obtaining input, output, but also process factors. Before conducting the research, we performed a reliability and a validity test. The questionnaire was tested at the pilot stage of the research, before the main phase of data collection, which enabled the elimination or rearrangement of inappropriate questions. The term "inappropriate" is used in a statistical sense to indicate that a particular question is unusual. This contains no implication as to whether the question is right or wrong (Easterby-Smith, Thorpe, \& Lowe 2005, 164-168). Companies in which we tested the understanding of the questionnaire were later not included in the research. Based on their observations and recommendations we complemented the questionnaire. The final version was later sent to the representatives of 410 companies. For a dedicated sample we selected four clusters or development centres in the field of metal-processing industry in Slovenia, which are currently in the association of clusters and technology networks at the Chamber of Commerce and Industry of Slovenia, namely: ACS 


\section{Journal of Contemporary Management Issues}

- Automotive Cluster of Slovenia (59 members) (ACS, 2010), TCS - Toolmakers Cluster of Slovenia (39 members) (TCS 2010), TECOS - Slovenian Tool and Die Development Centre (92 members) (TECOS, 2010), VTG - Cluster of HighTech Equipment Manufacturers (16 members) (VTG, 2010).

The sample was supplemented with companies that are members of the metal industry at the Chamber of Commerce and Industry of Slovenia and, according to our data, are not members of the strategic business alliances or clusters (265 members) (GZS, 2010). Secondary data, such as data on value added and profit per employee in companies and data on value added and profit per employee in the production of metal and metal products, were obtained through public agencies, such as the Agency of the Republic of Slovenia for Public Legal Records and Related Services (henceforth referred to as the AJPES) and the I-BON service.

For the hypotheses testing, we used parametric and non-parametric statistical tests. For the $\mathrm{H} 1$ verification, the t-test for independent samples was used. Beforehand, the equality of variances was checked with the Levene test and, based on the outcome, a suitable version of the t-test was chosen. The independent variable was the involvement in strategic business alliances (yes or no) and the dependent variable was the level of open innovation.

$\mathrm{H} 2$ was tested with the t-test for the arithmetic mean. Regarding the employees of all the companies, which are combined into strategic business alliances in the metal processing industry, the data on value added per employee and profit per employee was collected from the AJPES business database. With the t-test, we checked whether the business results of companies that are involved in strategic business alliances are below or above average, in comparison to the sector in general.

\section{RESEARCH RESULTS}

Among the 115 valid questionnaires slightly more than a half $(\mathrm{N}=59 ; 51.3 \%)$ came from companies that are involved in strategic alliances, while the rest are not included $(\mathrm{N}=56,48.7 \%)$.

\subsection{Number of innovations in both groups of companies}

Companies involved in strategic alliances have introduced an average of 42.8 innovations in the past five years, while companies without such links introduced an average of only 35.2 innovations. Given the high variability of the data, we have created classes and then compared the groups of companies. Following the grouping, it is evident that the share of companies that have introduced more than 10 innovations stands at $44.8 \%$ (included in strategic alliances) and among those not involved in the strategic alliances, it stands at only $30.4 \%$. On the other hand, there are only $5.2 \%$ of companies (involved in strategic alliances) that have introduced only one innovation and as much as $21.4 \%$ of those which are not included in strategic alliances. Furthermore, the share of companies that are involved in strategic alliances and have developed between 6 and 10 innovations stands at $27.6 \%$, while the share of companies in the class between two and five innovations reaches $22.4 \%$. The share of companies that are not involved in strategic alliances and have developed between 6 and 10 innovation accounts for $19.6 \%$, while the share of companies in the class between two and five innovations stands at $28.6 \%$ (Figure 1). 


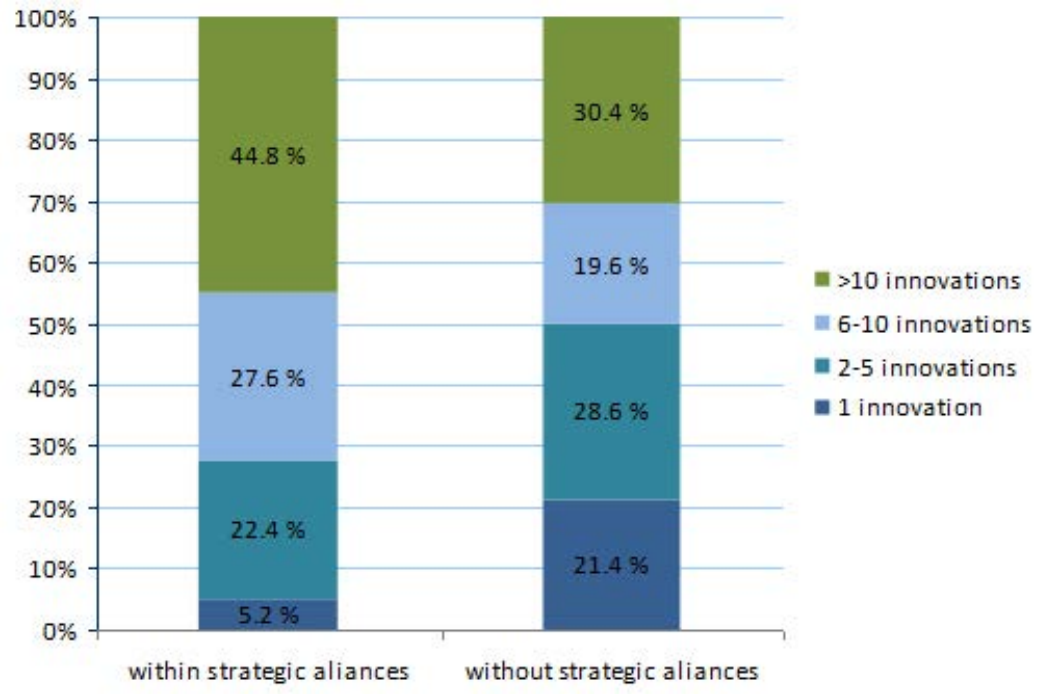

Figure 1. Number of introduced innovations in companies

Based on the chi-square statistics, which amounts to $8.49(\mathrm{p}=0.037)$ we can confirm that the companies involved in strategic alliances are more innovative. Also, the Mann-Whitney test, which checks the difference between the average range, confirms a statistically significantly higher number of innovations among companies involved in strategic alliances with the following partners: with customers $(z=-3.857, p=0.0001)$, with strategic partners $(z=-3.934, p=$ 0.001 ), with universities and institutes ( $\mathrm{z}$ $=-2.705, p=0.007)$ and with regional or local development and research agencies $(\mathrm{z}=-4.101, \mathrm{p}=0.001)$. Companies which are not involved in strategic alliances have by themselves introduced more innovations than companies that are involved in strategic alliances $(\mathrm{z}=$ $-2.577, \mathrm{p}=0.01)$. Looking at the total number of innovations with partners, it can be seen that the companies involved in strategic alliances launched more in- novation with partners than the companies that are not involved in strategic alliances $(z=-4.497, p=0.001)$.

\subsection{Level of open innovation}

In the next steps, focus was on the study of the level of open innovation. The criterion was defined in two ways, namely:

- OI_1: the share of innovations with respect to all innovations that the company developed either with customers, strategic partners, suppliers, universities and institutes, or regional or local development research agencies in joint innovation and

- OI_2: the number of different types of partners.

\subsection{Hypotheses testing}

$\mathrm{H} 1$ is checked by the t-test for the independent samples. The dependent variables are the level of open innovation (1), which was calculated as a percentage of innovation which the company introduced with 
partners, among their innovation over the last five years, and the rate of open innovation (2), which represents the number of different types of partners. The independent variable is the (non)involvement of companies in strategic business alliances.

Table 1. Open innovation in relation to the (non)involvement of companies in strategic business alliances

\begin{tabular}{lllll}
\hline & $\begin{array}{l}\text { Member of strategic business } \\
\text { alliances or clusters }\end{array}$ & N & $\begin{array}{l}\text { Arithmetic } \\
\text { mean }\end{array}$ & $\begin{array}{l}\text { Standard } \\
\text { deviation }\end{array}$ \\
\hline OI_1 Level of open innovation $(1) *$ & Yes & 58 & 57.7 & 31.6 \\
& No & 56 & 19.0 & 24.4 \\
OI_2 Level of open innovation $(2) *$ & Yes & 58 & 2.6 & 1.6 \\
& No & 56 & 1.1 & 1.4 \\
\hline
\end{tabular}

Note: * Differences between the groups are statistically significant at $\mathrm{p}<0.01$.

Among the companies that are involved in strategic alliances, the proportion of innovation generated with their business partners (level of open innovation 1) amounts to $57.7 \%$, whereas between the remaining companies it amounts to $19.0 \%$. There are significantly higher values between companies that are involved in $t$ strategic business alliances $(t=7.3, p=0.0001)$.

The level of open innovation (2), which is related to the number of different types of business partners that the company developed the innovation with, among companies involved in business strategic alliances, amounts to 2.6, while the level of open innovation (2) among companies without strategic business alliances amounts to 1.1. There are significantly higher values between companies that are involved in strategic business alliances $(\mathrm{t}=5.5, \mathrm{p}=0.0001)$. Thus, H1 can be confirmed.

In order to verify the $\mathrm{H} 2$, the value added per employee for the companies involved in strategic alliances was checked with the t-test for the arithmetic mean if the value added per employee is statistically significantly higher than average value added in the metal industry, which amounts to 31,748 EUR.

Table 2. Value added per employee and the t-test for the arithmetic mean (companies involved in strategic alliances with respect to all companies in the industry)

\begin{tabular}{llllll}
\hline & \multirow{2}{*}{ Arithmetic mean } & \multirow{2}{*}{$\begin{array}{l}\text { Standard } \\
\text { deviation }\end{array}$} & & \multicolumn{3}{c}{\begin{tabular}{c} 
Industry average \\
\cline { 3 - 6 }
\end{tabular}} & & & $\mathbf{t}$ & $\mathbf{g}, 748$ EUR $)$ \\
\hline Value added per employee & 37,412 & 15253.517 & 4.085 & 120 & 0.000 \\
\hline
\end{tabular}

Measured value added per employee for companies involved in strategic business alliances amounts to 37,412 EUR and is statistically significantly higher than the industry average, which amounts to 31,748 EUR $(\mathrm{t}=4.09, \mathrm{p}=0.00001)$. The hypothesis in this part is confirmed. Furthermore, we tested whether the net profit per employee in companies involved in strategic business alliances is higher than the industry average. 
Table 3. Net profit per employee and the t-test for the arithmetic mean (companies involved in strategic alliances)

\begin{tabular}{llllll}
\hline & \multirow{2}{*}{ Arithmetic mean } & \multirow{2}{*}{$\begin{array}{l}\text { Standard } \\
\text { deviation }\end{array}$} & & \multicolumn{3}{c}{\begin{tabular}{c} 
Industry average \\
\cline { 3 - 6 }
\end{tabular}} & & $\mathbf{1}, \mathbf{4 2 7}$ EUR) \\
\hline Net profit per employee & 4,733 & 8056.14 & 4.42 & $\mathbf{g}$ & $\mathbf{p}$ \\
\hline
\end{tabular}

For the metal industry, the net profit per employee amounts to 1,427 EUR, while the net profit per employee in companies involved in strategic business alliances amounts to 4,733 EUR. It is statistically confirmed $(\mathrm{t}=4.42, \mathrm{p}=0.0001)$ that these companies have above-average net profit per employee. The hypothesis is confirmed in this part as well. Based on the findings of both partial hypotheses, the second hypothesis may also be confirmed.

At the same time, we wanted to take another step towards understanding the causes of a more open and commercially successful innovation. Focus was given on the analysis of a comprehensive approach to innovation, which was measured with seven indicators. The companies indicated how many times in the past ten years they have been selected as an innovative company in the Republic of Slovenia, how many innovators they have, how many new products they have placed on the market, how many organizational innovations they have introduced, how many times they have improved the style of management, business model and business procedures or processes. Based on the responses we prepared a table of average values, which gives an assessment of those indicators (Figure 2).

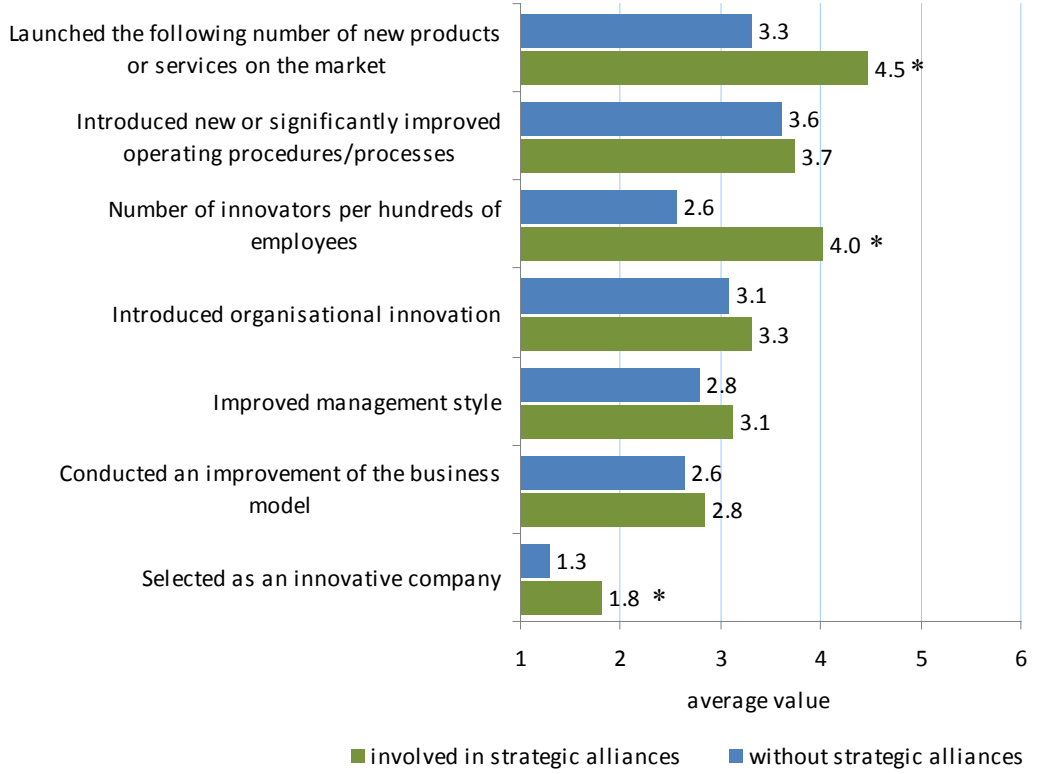

Figure 2. Integrity of innovation in relation to the (non)involvement in strategic alliances - t-test for independent samples

Note: * Significant differences. 


\section{Journal of Contemporary Management Issues}

T-test for independent samples of indicators was also conducted, which defines the integrity of innovation in relation to the (non)involvement in strategic alliances. Comparison of the average values of the responses shows that the companies that are involved in strategic alliances, placed more new products or services on the market $(\mathrm{t}=3.31, \mathrm{p}=0.001)$, have a larger number of innovators per hundred employees $(\mathrm{t}=4.17, \mathrm{p}=0.0001)$ and have been more often selected as an innovative company $(t=2.42, p=0.017)$. This is also evident from the comparison of the frequency distribution.

\section{SUMMARY OF RESULTS AND DISCUSSION}

In this article, the relationship and interaction between strategic business alliances and open innovation were discussed. Particular attention was dedicated to the factors that characterise both strategic business alliances and open innovation, and the assessment of the influence of strategic business alliances in the metal industry on the perception and internalization of open innovation.

The companies involved in strategic alliances have introduced an average of 42.8 innovations in the past five years, while companies without any such links introduced an average of only 35.2 innovations. It was discovered that the companies involved in strategic business alliances are more innovative and create more innovations in cooperation with customers, strategic partners, universities and institutes, as well as regional or local development and research agencies. We were also interested in the degree of open innovation. To this end, two indicators were created. The first one represents the portion of innovations that have occurred in the company, on the basis of cooperation with partners, while the other one represents the number of partners that were involved in any such work. With the help of these indicators, two hypotheses were checked. Confirming the first hypothesis, we found that companies that are involved in strategic business alliances have a higher level of open innovation. We demonstrated that the factor of strategic business integration is typically associated with an innovative collaboration between universities and research institutions on the one hand, and production and service systems, on the other hand, as well as with cooperation with the entire supporting environment of a company. With the help of selected analytical methods, the research showed that companies that are already in strategic business alliances have a higher level of open innovation.

With the second hypothesis, we checked whether the business results of companies that are involved in strategic business alliances are above average, in comparison to their sector. Here, we are aware of the fact that with the comparison of performance indicators, such as value added per employee, net profit per employee, profit per employee etc., companies may determine whether they are relatively better or worse than the comparative companies or industries. Yet, they do not get the answer to the question as to why they are better, or worse. The hypothesis was verified through two partial hypotheses. Within the first, we were interested in the value added, with respect to involvement in strategic alliances and within the other one, in the net profit of companies. In the first step, it was determined that value added per employee for companies involved in strategic business alliances, amounts to 37,412 EUR and is statistically significantly higher than the industry average, which amounts to 31,748 EUR. In the 
second step, it was determined that for the metal industry, the net profit per employee amounts to 1,427 EUR, while the net profit per employee in companies involved in strategic business alliances amounts to 4,733 EUR. Here, too, the differences are statistically significant. Based on the findings of both partial hypotheses, the second hypothesis was confirmed, as well with the conclusion that the business results of the companies involved in strategic business alliances are above average, in comparison to the sector in general.

Presented findings confirm the Chesbrough's indications (2003, 178-194), which state that, for the transition from a closed innovation model to a model of open innovation and for the creation of the value added, it is reasonable to consider the following factors:

- conduct cooperation with universities and other partners,

- check external technology with external experts and apply technologies and ideas from elsewhere,

- in-company R \& D departments must be in regular, direct contact with the key customers and suppliers,

- less research should take place within the company,

- it is recommended to share the research with public research institutions and universities, especially in its earlier stages.

However, we should be aware of the fact that the division of labour requires more cooperation, which in turn depends on the adequacy of the business model. The success of business networks in conjunction with open innovation is already defined by Dittrich (2007), who describes the use of innovation networks as means to adapt swiftly to changing market conditions and strategic change.

As regards the financial effects of strategic alliances, it is worth mentioning that Faems (2010) showed that the technology alliance portfolio diversity has an indirect positive impact on financial performance, via increased product innovation performance. It is achieved via a positive impact on internal innovation efforts, which increases product innovation performance. He also suggests that, when making technology alliance decisions, managers not only should consider the potential benefits of such collaborative strategies, but also should take into account the additional costs of intensifying the technology alliance portfolio. Even though we have not studied the related costs, his findings are in line with ours. Regarding the latter, based on the analysis of the integrity of innovation, we note that strategic business alliances members have a broader spectrum, or range of innovations, than companies that are not involved in strategic business alliances. This offers us the answer that these companies are more innovative. since they are more active with their invention-innovation activities in several areas.

\subsection{Practical implications}

The crucial massage is that fruitful cooperation can be established by following the doctrine of open innovation which leads to quantitatively greater number of innovations and especially to higher value added and better economic results.

This research proved that, through strategic business relationships, companies successfully switched from a model of closed innovation model to OI, mostly due to previous participation in other fields, knowledge of each other's culture, trust, openness and integrity in business, wish to achieve 


\section{Journal of Contemporary Management Issues}

common goals, etc.. Knowledge and ideas can be transmitted more easily with an innovative collaboration than on the open market, and the conditions for mutual benefit may be created more easily, such as the acquisition of new knowledge, innovation and the opportunity to participate in major projects, as well as the possibility of improving long-term performance of companies and the establishment of appropriate culture and climate of innovation. Similar conclusions were supported by Muller, Hutchins and Pinto (2012, 39-40).

\subsection{Limitations and suggestions for further research}

This study was oriented towards metal-processing industry in Slovenia, which poses two limitations. Its results cannot be directly applied to other industries, due to different technological background and other industry properties. On the other hand, the results cannot be directly transferred to other countries. Therefore, for further research it would be interesting to perform an international study and to check whether the results are similar in other countries. We also believe that companies, working within international networks, reach even better business results, compared to those which are limited to national clusters and strategic alliances. We also believe that different industries show different patterns, related to the topic of this paper. Hence, we would suggest including different branches or follow the segmentation to e.g. low and hitech sectors and making a comparison.

An important research result would also be comprising a set of guidelines, related to cooperation policy, which would contribute to better business results. Therefore, such guidelines should be determined. A qualitative research approach would be suggested. On the other hand, companies often fear talking about cooperation with competitors. For that reason, it would be interesting to investigate how companies overcome such fear and where there is a limit in cooperation related to non-wanted drain of ideas, intellectual property, know-how and employees.

\section{CONCLUSION}

In terms of scientific contribution, we have confirmed that open innovation may lead to cooperation and quantitatively greater number of innovations, as well as to their better quality. Innovations that are created in cooperation with external partners also bring higher value added and better economic results, which is reflected in companies' higher net profit. One of the reasons for this finding is that the companies involved in strategic business alliances manage the process of innovation more comprehensively. On the basis of the research results, it may be concluded that strategic business alliances represent the bridge in the transformation from a closed innovation model to the open innovation model.

\section{REFERENCES}

1. ACS (2010). Slovenski avtomobilski grozd. Http://www.acs-giz.si/slo/ domov.asp

2. Betz, F. (1993). Strategic technology management. McGraw-Hill.

3. de la Sierra, M. C. (1995). Managing global alliances: Key steps for successful collaboration. Addison-Wesley.

4. Chesbrough, H. W. (2003). Open innovation: The new imperative for creating and profiting from technology. Harvard Business Press.

5. Dittrich, K., \& Duysters, G. (2007). Networking as a means to strategy change: the case of open innovation in mobile telephony. Journal of 
product innovation management, 24(6), 510-521.

6. Dolinšek, S. (2004). Management tehnologij: učinkovito obvladovanje tehnoloških sprememb: skripta. Fakulteta za management.

7. Drejer, A. (2008). Are you innovative enough?. International Journal of Innovation and Learning, 5(1), 1-17.

8. Dubrovski, D., \& Ježovnik, A. (2009). Strateške poslovne zveze in kapitalske povezave. Koper: Fakulteta za management.

9. Easterby-Smith, M., Thorpe, R., Lowe, A., Sedmak, M., Ježovnik, A., \& Adam, F. (2005). Raziskovanje v managementu. Koper: Fakulteta za management.

10. Faems, D., De Visser, M., Andries, P., \& Van Looy, B. (2010). Technology alliance portfolios and financial performance: value-enhancing and costincreasing effects of open innovation. Journal of Product Innovation Management, 27(6), 785-796.

11. GZS. (2010). Združenje kovinske industrije. Predstavitev združenja. http://www.gzs.si/slo/panoge/ zdruzenje_kovinske_industrije

12. Hobday, M. (2005). Firm-level innovation models: perspectives on research in developed and developing countries. Technology analysis \& strategic management, 17(2), 121-146.

13. Konda, I. (2010). Dejavniki uspešnosti omrežja povezav med prodajalci in kupci na medorganizacijskem trgu. Our Economy (Nase Gospodarstvo), 56, 92-100.

14. Kopac, J. (2003). Concurrent engineering in theory and practice. Strojniski Vestnik, 49(12), 566-574.
15. Likar, B. (2008). The influence of innovation, technological and research processes on the performance of Slovenia's woodworking indus-try. Wood Research, 53(4), 115-120.

16. Strašek, A., Likar, B. (2016). Strategic business alliances as a bridge towards open innovation and improved business performance. 2nd International conference on multidisciplinary academic research \& global innovation, August, 25-26, Beijing: MARGI 2016. Beijing: Global Illuminators, 1-5. http:/globalilluminators.org/conferences/margi-2016/ margi-full-paper-proceeding-2016/

17. Lindegaard, S. (2011). Making Open Innovation Work:@lindegaard to Big and Small Companies. CreateSpace.

18. Ostojić Mihić, A., Umihanić, B., \& Fazlović, S. (2015). The role of organizational innovation in achieving and maintaining company's business excellence. Management: Journal of Contemporary Management Issues, 20(1), 79-100.

19. TCS (2010). Slovenski orodjarski grozd. Http://www.toolscluster.net/sog. php

20. TECOS (2010). Razvojni center orodjarstva Slovenije. http://www.tecos.si/

21. UNU-MERIT. (2012). Innovation Union Scoreboard 2011 - Research and Innovation Union scoreboard. Maastricht Economic and social Research and training centre on Innovation and Technology, Maastricht.

22. VTG (2010). Grozd proizvajalcev visoko tehnološke opreme. http://www. vtg-giz.si/ 


\section{OTVORENA INOVACIJA I UNAPREĐENJE POSLOVNIH REZULTATA U STRATEŠKIM POSLOVNIM SAVEZIMA}

\begin{abstract}
Sažetak. Razlog ovog istraživanja je utvrditi imaju li poduzeća, uključena u strateške poslovne saveze, višu razinu otvorenih inovacije i poslove rezultate u metalskoj industriji $u$ jednoj zemlji-članici EU-a (Sloveniji). Anketom je obuhvaćeno 115 poduzeća, u kojoj su analizirane prethodno spomenuti odnosi i utjecaji, korištenjem odgovarajućih statističkih metoda (Mann-Whitneyevim testom, Hi-kvadrat testom, t-testom, itd.). Uzorak je uključivao četiri klastera poduzeća te centara za istraživanje i razvoj iz metalske industrije. Rezultati su pokazali da strateški poslovni savezi imaju značajan utjecaj na otvorenu inovaciju u poduzećima, kao $i$ na učinkovitost suradnje sa sveučilištima $i$ istraživačkim institucijama. Među poduzećima, uključenim u strateške saveze, udjel inovacija, stvorenih u suradnji s poslovnim partnerima
\end{abstract}

iznosi 57.7\%, dok je, kod poduzeća izvan strateških saveza, vrijednost istog indikatora 19\%. Nadalje, rezultati su pokazali da je većina poslovnih rezultata, u poduzećima angažiranim $u$ strateškim savezima, natprosječna, u odnosu na industrijski prosjek. Dodana vrijednost po zaposlenom u ovim je poduzećima bila značajno veća od industrijskog prosjeka, kao i dobit, za koju je razlika bila više od trostruke. Može se zaključiti da strateški savezi predstavljaju značajan alat za transformaciju zatvorenog prema otvorenom modelu inovacije, uz bolje poslovne rezultate. Značajna implikacija za poduzeća odnosi se na poruku da suradnja s konkurentima može donijeti dodanu vrijednost za sve uključene.

Ključne riječi: inovacija, strateški savezi, otvorena inovacija, poslovni rezultati 